\title{
Rare plants on Mount Oku summit, Cameroon
}

\author{
Fiona G. Maisels, Martin Cheek and Chris Wild
}

\begin{abstract}
The forests of the Kilum-Ijim area, around Mount Oku in West Cameroon, are the largest remaining patch of montane forest in West Africa, and the highest in altitude. This important habitat harbours endemic species of both animals and plants but is surrounded by a high density of human settlements: c. 300,000 people live within a day's walk of the forest, which covers only $200 \mathrm{sq} \mathrm{km}$. BirdLife International and the Ministry of the Environment and Forestry, Government of Cameroon, are currently operating the KilumIjim Forest Project, with the overall goal of conserving representative areas of the Cameroon montane forest biome in the long-term. The purpose of the project is to
\end{abstract}

ensure that the biodiversity, extent and ecological processes of the Kilum-Ijim Forest are maintained and that the forest is used sustainably by the local communities. The existence of a small Sphagnum community and associated wetland plant species was discovered in 1997 on the summit of Mount Oku, at $2900 \mathrm{~m}$. This site is of extremely high conservation importance because several plant species endemic to the Kilum-Ijim area have been recorded there. In addition, it is the highest Sphagnum bog and the source of the highest stream in West Africa.

Keywords Cameroon, conservation management, endemic species, flora, montane habitats.

\section{Introduction}

Mount $\mathrm{Oku}$ is part of a mountainous area known as the Kilum-Ijim Forest. This forest lies between $6^{\circ} 05^{\prime}$ and $6^{\circ} 20^{\prime} \mathrm{N}$ and $10^{\circ} 20^{\prime}$ and $10^{\circ} 36^{\prime} \mathrm{E}$ in the Bamenda Highlands, North-West Province, Cameroon. The area is part of the Cameroon Highlands, a mountain chain of plutonic and volcanic origin that runs north-east from the coast (Mount Cameroon) to the Bamboutos and Bamenda highlands, and through to the Tchabal Mbabo mountains further north.

The montane forests of the Cameroon Highlands are considered to be a priority area for conservation on a global scale. Data collected on different taxa show the Cameroon Highlands to be of high biological importance for many taxa (Stuart, 1986; ICBP, 1992). Along with the southern side of Mount Cameroon, the mont-

\section{Fiona G. Maisels Kilum-ljim Forest Project, BirdLife} International/Ministry of the Environment and Forestry, Cameroon, PO Box 119 Kumbo, North-West Province, Cameroon. Fax: c/o CSS Banso + 237481463 (address for correspondence Birdlife International, Wellbrook Court, Girton Road, Cambridge CB3 ONA, UK. Tel: + 441223 277318; fax: + 441223 277200) and ICAPB, Ashworth Laboratories, Edinburgh University, Kings Buildings, West Mains Road EH9 3JT, UK.

Martin Cheek (corresponding author) Royal Botanic Gardens Kew, Richmond, Surrey TW9 3AB, UK. Tel: + 44181332 5434; fax: +44 181332 5278; e-mail: m.cheek@rbgkew.org.uk

Chris Wild Mount Kupe Forest Project, WWF Cameroon, PO Box 2417, Douala, Cameroon. ane forests of Mount Oku were considered to have the highest conservation priority for plants among the montane forest ecosystems of Cameroon (Thomas, 1986). Similarly, of 75 African forests reviewed for their conservation status by Collar \& Stuart (1988), the forests of Mount Oku were considered 10th equal in terms of priority ranking; this was based not only on birds as indicators but on the high degree of biological differentiation and the degree of threat to the forests. Birds have been shown to be good indicators of biodiversity and endemism in other taxa (ICBP, 1992; Bibby, in press). These highlands are classified as 'critical' in a hierarchy of priority listings of Endemic Bird Areas around the world (ICBP, 1992; Stattersfield et al., 1998).

Many montane forests in Cameroon remain biologically unknown and probably also support remarkable biodiversity of viable conservation potential. The remaining forest on Mount Oku lies between 2000 and $3000 \mathrm{~m}$ above sea level; forests of the lower altitudes have already been cleared, either for agriculture or for grazing land. Mount Oku supports montane forest up to $3000 \mathrm{~m}$-the highest in West Africa (Letouzey, 1985) - although large patches have been destroyed on the flatter tops to create pastureland.

In Cameroon, the mountain habitats can be subdivided into the Afromontane zone below $2800 \mathrm{~m}$ and the sub-Afroalpine zone above $2800 \mathrm{~m}$ (Letouzey, 1985). Thus, in West Africa, the sub-Afroalpine zone is found only on Mount Oku and Mount Cameroon, although it is much damaged on Oku as a result of both fire and 
overgrazing (Letouzey, 1985; ENGREF, 1987; Macleod, 1987; Tame \& Asonganyi, 1995).

BirdLife International (formerly the International Council for Bird Preservation) has been involved in forest conservation in the Kilum-Ijim area since 1987. The challenges faced by the project have been considerable: the process of species extinction probably began over 200 years ago with the loss of the megafauna, including notable species such as elephant (several generations ago), buffalo (at least 20 years ago), species of antelope, etc. In addition, at least one key bird frugivore, the great blue turaco Corythaeola cristata, which is important for the dispersal of tree seeds, is known to have been lost. Remaining large mammal populations are severely depressed and are close to regional extinction. The long-term consequences of these extinctions are uncertain but they have probably already had deleterious effects on ecosystem stability and forest regeneration.

By 1986, the forest had been reduced to 50 per cent of its extent in 1963 (ENGREF, 1987; Macleod, 1987); the Kilum and Ijim Mountain Forest Projects (now called the Kilum-Ijim Forest Project) were thus set up to prevent further loss of forest and to help provide sustainable alternatives to forest clearance. The project has had some success: the Kilum-Ijim forest now has a boundary that has been agreed in collaboration with the surrounding communities. As a result, conversion of forest to farmland ceased in 1992 (KilumIjim Forest Project: Annual Reports, 1993-97). However, in addition to the clearing of forest, other serious human influences on montane forest are still active: these include forest fires and the use of the forest for grazing animals, especially goats, which browse on regenerating trees. Although it is thought that high grazing pressure inhibits forest regeneration, the ecological role of goats in the near absence of natural indigenous herbivores (now hunted out) is unclear. Despite the loss of biodiversity, the forest, albeit intensively exploited, remains a key conservation site within the Cameroon montane biome and is an important test case for participatory forest management. In the future, it is envisaged that the forest will be managed by the local communities with technical advice and input from the Ministry of Environment and Forestry (MINEF). This is currently being facilitated by the Kilum-Ijim Forest Project.

Collections of the flora of Mount Oku and the adjoining area, the Ijim Ridge, have been reviewed by Cheek et al. (1997). These authors carried out extensive surveys of the area during the Royal Botanic Gardens (RBG), Kew/National Herbarium of Cameroon (NHC) expeditions in 1996 and found several new species, including three species of Eriocaulon
(Phillips, 1998), one new subspecies of Indigofera, one new Pentarrhinum, a new Oxyanthus and a member of the Flacourtiaceae, which appear to be strictly endemic to the Kilum-Ijim area, as well as several near-endemic taxa: Succisa trichotocephala, Dipsacus narcisseanum, Butumia marginalis and Ledermanniella keayi (Cheek et al., 1997). Near-endemic refers to taxa that have been found in the Kilum-Ijim area and at only one other site. Previous workers had concentrated on the flora of the montane forests, and the Kew/NHC team found that some habitats had been undercollected, namely waterfalls, lakeside, seasonally wet, rocky areas and wetlands (Cheek et al., 1997).

\section{Rediscovery of Kniphofia reflexa}

A species that had only ever been collected from one site and on one occasion is Kniphofia reflexa (Asphodelaceae). The type (and until 1996 the only) specimen was collected at Laikom (northern part of the Ijim area) in 1936 (Hepper, 1968, p. 94). It was flowering in April 1936 at $6000 \mathrm{ft}(1828 \mathrm{~m})$.

Maitland (cited in Hepper, 1968), who was the original collector of the species, described it as 'A tufted perennial herb with a single sterile, inflorescence about 2 feet high; flowers small, campanulate, yellow; scattered in considerable numbers in the grass on the plateau'. In addition, Hepper (1968) added the following measurements: 'leaves ... up to $60 \mathrm{~cm}$ long and $1.5 \mathrm{~cm}$ broad; spike stout, about $60 \mathrm{~cm}$ long... perianth $\ldots 1 \mathrm{~cm}$ long'.

During the survey, the Kew/NHC team made an exciting discovery. They found a population of seven individuals of $K$. reflexa in the Afua wetland, an area of about $700 \times 1500 \mathrm{~m}$, at about $2200 \mathrm{~m}$, above Belo village. The spikes were in fruit (November 1996) and about $2 \mathrm{~m}$ tall. A second visit was made to the Afua area in November 1997 by one of the authors (F.M.) and five individual clumps were found, one of which was in fruit and about $1 \mathrm{~km}$ away from the others; the remaining four clumps had no fruiting or flowering spikes (nor any sign of last year's spikes) and comprised 11 'individuals', although it is probable that these were four individuals that had reproduced vegetatively by stolons or rhizomes. All of the plants were growing with their roots in water, the fruiting individual in the middle of $1-2-\mathrm{m}$ tall Schoenoplectus brachyceras and the others in a boggy stream by the edge of low scrub. On 3 May 1997, another population was discovered on Kilum (Oku) summit, at $2900 \mathrm{~m}$. This population was in a spring-fed oligotrophic boggy stream, which arose from a SphagnumJuncus area only about $15 \mathrm{~m}$ across, and ran down for about $100 \mathrm{~m}$ before falling over a cliff into montane 
forest. The area is known as Kinkolong. Most of the plants have their bases in slowly running water, at least during the wet season, and are found along the stream and bog edges, which is rather different from the habitat description of Maitland. The area does not dry up entirely in the late dry season (January-February). This population numbered several hundred plants but fewer than 10 were in flower. A return visit was made on 15 May. On this occasion, only six were in flower. Three subsequent visits were made throughout the wet season (June-October 1997) and on 26 October, when all flowering and fruiting spikes were counted. They numbered 475. On the latter date, about one-third of the spikes were flowering and the rest bore fruit. Thus, flowering extends from at least early May to late October at this altitude, and fruiting continues until at least November.

Since the discovery of this population, a further two sites have been added to the list for this species: the Mbesa plateau (a few kilometres from where the original type specimen was discovered, within the boundaries of the Kilum-Ijim forest); and in a wetland in an extinct crater a few kilometres from the Afua site called the Mbi Crater Game Reserve. Both of these populations number about 200 individuals. Thus, the Kinkolong stand may prove to be the world's largest population of this species.

Measurements were made of the height of the flowering spikes and of the leaf widths. Leaves of different individuals were uniform: $14-16 \mathrm{~mm}$ wide $(14.7 \pm$ $0.6 \mathrm{~mm} ; n=8$ ); flowering spikes were $60-160 \mathrm{~cm}$ tall and fruiting spikes were even taller-up to $2 \mathrm{~m}$. Each plant appeared to consist of several basal rosettes along a line of $2-3 \mathrm{~m}$, presumably arising from a common stolon or rhizome.

\section{Conservation importance of the site}

The summit of Mount Oku is currently heavily grazed by goats, sheep and cattle. This is not an indigenous practice but is a relatively new occurrence, which has intensified greatly since the early $1980 \mathrm{~s}$. In the past, tradition prevented large numbers of animals from entering the forest. When the Kilum-Ijim Project began in 1987, most of the livestock were removed from within the forest boundaries; however, in the early 1990s (1994 onwards), this process was reversed and many stock were taken into the forest again.

The Kinkolong bog site also holds a population of several hundred individuals of Succisa trichotocephala, a near-endemic species to Kilum-Ijim. It occurs only at Mount Cameroon and in the Kilum-Ijim area, Laikom and above Lake Oku (Hepper, 1963; Cheek et al., 1997), and on several grassy areas on the Ijim Ridge and the Oku summit (F. G. Maisels, pers. obs.). We also noted one of the three Eriocaulon sp. nova referred to earlier flowering in July. We photographed but did not collect it because it seemed to be very rare. When we returned to the site to collect a fruiting head of the Eriocaulon, because the fruit had not yet been described, we searched without finding the plant where it had been growing in July. There were signs of heavy grazing at the spot (all of the tall Schoenoplectus that had been there earlier were eaten to the ground); therefore, the plant may have been destroyed by goats or sheep. Some of the Kniphofia had suffered grazing by stock and others had been trampled. About 100 individuals of this Eriocaulon sp. nova were later noted $100 \mathrm{~m}$ downstream of the original site.

Also present in this wetland area, at its first recorded location in West Africa, is Juncus dregeanus (Maisels 46, $K, Y A)$. This specimen may represent a new subspecies to science if it proves not to be the eastern African $J$. dregeanus subsp. bachittii (J. Kirschner, pers. comm.). Associated wetland species present at this site are: Sphagnum strictum subsp. pappeanum (Maisels 145, 148, K, YA); Philonotis cf. microthamnia (Maisels 147, 155, K, YA); Leptodontium viticulosoides (Maisels 154, K, YA), and Meiothecium sp.? and Daltonia minuta (both Maisels 156, K, YA) (all bog mosses); Xyris sp. A, Lobelia minutula (Mount Oku is its only known site in West Africa); and Satyrium sp.

We await final analysis of these and 10 other species from this site, most of which do not seem common or are absent below $2000 \mathrm{~m}$, even where wetland habitats can be found.

High-altitude Sphagnum bogs are rare in West Africa. Although Mount Cameroon $(4100 \mathrm{~m})$ is high, it has no permanently wet montane habitats-probably because of the free-draining volcanic substrate-and the sole Sphagnum sites known, at $2400 \mathrm{~m}$, occupy only 1-2 sq m each and do not support a bog community (M. Cheek, pers. obs.). There is also an extensive cloud-forest Sphagnum bog community at Lake Edib, a pristine crater lake situated at $1200 \mathrm{~m}$ in the Bakossi mountains, SouthWest Province, and adjacent to Mount Kupe, but no Kniphofia, Juncus or Eriocaulon have been found at this site (M. Cheek, pers. obs.). The site is suspected to be the largest known montane Sphagnum bog community in the Congolian coastal forest belt or West Africa and is currently the subject of intensive research by WWF Cameroon and RBG, Kew.

The practice of keeping stock inside the forest on Mount Oku is banned by both the Traditional Authorities and the Administration. Traditionally, the local communities around the forest were heavily dependent on the forest for secondary forest products, especially firewood, medicinal plants, honey, alpine bamboo, etc. This is epitomized by the all-important role that the 
forest plays in the rich cultural life of the people. Some unsustainable forest exploitation practices have long been controlled by the Traditional Authorities of the region. In July 1993, on recognizing the grazing problem, the Oku Clan Council decreed that all domestic animals should be removed from the forest. Finally, a Prefectorial Order (an Administrative Order issued by the Senior Divisional Officer, Government of Cameroon) was passed in 1993, which prohibited the following activities within the forest boundary: lighting bush fires, tree felling, cutting of young alpine bamboo, farming, hunting/trapping of animals in the forest reserve (unless for rats, using traditional methods), and the rearing and grazing of domestic animals. Thus, both the traditional authorities and the government recognize the fact that grazing of livestock within the forest boundary is detrimental to the long-term survival of the forest and montane vegetation. This important sub-Afroalpine site should merit particular conservation attention because sub-Afroalpine Sphagnum bog communities are exceptionally rare in the region, and probably represent the single rarest habitat type in the forest zone of Africa, in terms of both area and frequency.

\section{Management}

Several well-established techniques for wetland plant management exist in temperate climates such as the UK (Sutherland \& Hill, 1995). These include seasonal and rotational grazing at various densities by hardy breeds of sheep, horses and cattle, as well as traditional methods such as seasonal and rotational cutting using a variety of tools. Management regimes are necessarily site-specific and are dependent on local ecological processes and land-use threats, especially with regard to local hydrological processes. However, the role of domestic herbivores (i.e. goats and cattle) in the maintenance of floral diversity of the Kinkolong wetland is currently unclear. It is clear that this habitat type is natural, because of the presence of various endemic taxa found at the site. Currently, livestock grazing on the summit is a conservation issue for tree regeneration. Further research and monitoring is considered to be essential for the future maintenance of biodiversity at this sensitive site. It is an important challenge for both the local community and the government to develop and implement a sustainable management regime.

\section{Acknowledgements}

The Kilum-Ijim Forest Project is a joint programme of BirdLife International and the Ministry of Environment and Forestry of Cameroon (MINEF). The project is currently funded by the Global Environment Facility (GEF), the British Department for International Development (DFID) and the Dutch Ministry of Agriculture. The 1996 survey carried out by the Royal Botanical Gardens (RBG), Kew, and the National Herbarium of Cameroon was supported by Earthwatch Europe, with assistance from DG VIII of the European Commission and GEF Cameroon. We would like to thank the indefatigable Isaac Fokom who has helped as a guide, pressman and enthusiastic assistant during plant collections at the summit of Mount Oku, and Martin Etuge who recollected the long-lost Kniphofia in 1996. We also thank the following specialists for naming specimens: Cliff Townsend (mosses), Mats Thulin (Campanulaceae), Mike Lock (Xyris), Sylvia Phillips (Eriocaulon), Jan Kirschner (Juncus) and David Goyder (Pentarrhinum). Finally, thanks to all the staff of the Kilum-Ijim Forest Project for their help with logistics and discussions, and for their good team spirit and friendship.

\section{References}

Bibby, C.J. (in press) Making the most of birds as environmental indicators. Ostrich, 70.

Cheek, M., Sabatie, B. \& Onana, J.-M. (1997) Interim Report on Botanical Survey and Inventory for Kilum and Ijim Mountain Forest Projects by the National Herbarium, Cameroon and Royal Botanic Gardens, Kew, Oct/Nov 1996 Royal Botanic Gardens, Kew and National Herbarium, Cameroon.

Collar, N.J. \& Stuart, S.N. (1988) Key forests for threatened birds in Africa. International Council for Bird Preservation Monograph No. 3. International Council for Bird Preservation, Cambridge, UK.

ENGREF (1987) Massif d'Oku, Cameroon. Classement en Reserve et Principes pour un Plan Directeur d'Amenagement. ENGREF, University of Montpellier, France and Centre Universitaire de Dschang, Cameroon [in French].

Hepper, F.N. (1963) Dipsacaceae. In Flora of West Tropical Africa, vol. 2, 2nd edn (eds F. N. Hepper and R. W. Keay), pp. 223-224. Crown Agents, London.

Hepper, F.N. (1968) Liliaceae and Juncaceae. In Flora of West Tropical Africa, vol. 3, 2nd edn (eds F. N. Hepper and R. W. Keay), pp. 90-107. Crown Agents, London.

ICBP (1992) Appendix 5: Priority Listing of Endemic Bird Areas. Putting Biodiversity on the Map: Priority Areas for Global Conservation (eds C. J. Bibby, N. J. Collar, M. J. Crosby, M. F. Heath, Ch. Imboden, T. H. Johnson, A. J. Long, A. J. Stattersfield and S. J. Thirgood), p. 81. International Council for Bird Preservation, Cambridge, UK.

Kilum-ljim Forest Project: Annual Reports (1993-97) BirdLife International. BirdLife International, Cambridge, UK and Kilum-Ijim Project, Kumbo, Cameroon.

Letouzey, R. (1985) Notice de la Carte Phytogeographique du Cameroun au 1:500000; Region Afro-montagnarde et Etage Submontagnard. IRA Yaounde, Cameroun/Institut de la Carte Internationale de la vegetation, Toulouse, France [in French]. 
Macleod, H. (1987) Conservation of Oku Mountain Forest, Cameroon. International Council for Bird Preservation Report no. 15, International Council for Bird Preservation, Cambridge, UK.

Phillips, S.M. (1998) Two new species of Eriocaulon from West Africa. Kew Bulletin, 53, 943-948.

Stattersfield, A., Crosby, M., Long, A.J. \& Wege, D.C. (1998) Endemic Bird Areas of the World. Priorities for Biodiversity Conservation. BirdLife International, Cambridge, UK.

Stuart, S.N. (ed.) (1986) The Conservation of the Montane Forests of Western Cameroon. Report of the International Council for Bird Preservation Cameroon Montane Forest Survey. International Council for Bird Preservation, Cambridge, UK.

Sutherland, W.J. \& Hill, D.A. (1995) Managing Habitats for Conservation. Cambridge University Press, Cambridge.

Tame, S. \& Asonganyi, J. (1995) Vegetation Survey of the Ijim Mountain Forests, Northwest Province, Cameroon. Report to BirdLife International/GEF World Bank/Ministry of the Environment and Forestry, Government of Cameroon.

Thomas, D.W. (1986) Vegetation in the montane forest of Cameroon. In The Conservation of the Montane Forests of Western Cameroon (ed. S. N. Stuart), pp. 20-27.
International Council for Bird Preservation, Cambridge, UK. Report of the International Council for Bird Preservation Cameroon Montane Forest Survey.

\section{Biographical sketches}

Fiona G. Maisels is a tropical-forest ecologist who is particularly interested in plant-animal relationships and conservation biology. Her work has been carried out mostly in Central African lowland forests, and for the last 2 years she has been the project ecologist for the Kilum-Ijim Forest Project.

Martin Cheek is a botanist with particular interest in African forest flora. He is officer for West and Central Africa at the Royal Botanic Gardens, Kew.

Chris Wild specializes in the herpetofauna of Cameroon and is also interested in nocturnal mammalian fauna of Africa. He is currently concentrating on surveys of cloudforest biodiversity in Cameroon. 